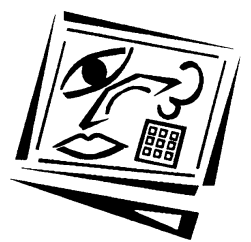

\title{
A framework for analysing ICT adoption in Australian primary schools
}

\author{
Jenni Way \\ University of Sydney \\ Colin Webb \\ University of Western Sydney
}

\begin{abstract}
Over 400 e-learning grant applications from Australian primary schools were analysed to determine the nature of the proposed ICT based projects in literacy and numeracy. Three key dimensions emerged from the teacher descriptions: ICT infrastructure, motivation and ICT use, and pedagogy and innovation. The three dimensions, and the interactions between them, provide a means for understanding the complex factors within an individual school that determine the nature of ICT use and the potential for innovation. Several types, or levels, were identified within each dimension, together forming a framework that can be applied as both a research tool and a model for describing in detail the current status of ICT use in a school.
\end{abstract}

\section{Introduction}

For a number of years many educators, administrators and researchers have asked the question, 'Why have teachers on the whole been so reluctant to integrate information and communication technologies (ICT) into their teaching practice?' Although many teachers use technology in multi-dimensional ways, in and out of the classroom, many more do not (Bebell, Russell \& O'Dwyer, 2004; Cuban, 2001; Sugar, Crawley \& Fine, 2004; Jamieson-Proctor, Burnett, Finger \& Watson, 2006; Smeets, 2004). Considering the saturation and high impact of technologies in the business world and the general community, pressure from government bodies, and the duty of schools to educate children for the future, the lack of utilisation of the capabilities of technology in so many schools has been perplexing (Phelps, Graham \& Kerr, 2004). The accumulated literature reveals four possible explanations; that some teachers perceive ICT to be incompatible with their wider educational beliefs, that there may be strong social obstacles to greater levels of integration, that there may be obstacles at the school level, or finally that the obstacles may be to do with the personal characteristics of some teachers, such as confidence (Becta, 2004; Jameison- 
Proctor et. al., 2006; Scrimshaw, 2004). However, the uniqueness of every teacher, the complexity of each school environment and the likely interaction between determining factors has made a comprehensive picture of what is happening in schools across Australia elusive (Ainley, Banks \& Flemming, 2002). Yet such a comprehensive national picture would provide valuable information for strategic planning to support the uptake of ICT on national, state, regional and individual school levels.

The 2002 Commonwealth Bank e-Learning Grants program provided $\$ 350,000$ in additional funding to primary schools across all states and territories and education sectors for literacy and numeracy projects. The 2002 e-Learning Grants program, through the grant application process, provided a timely opportunity to gain an insight into the ways in which teachers construct innovative learning projects incorporating online learning, within the context of their own school. It has also provided a national 'snapshot' of the levels of ICT infrastructure in primary schools. The continuation of the grants program in subsequent years also provided an invaluable opportunity to gain rich longitudinal data on changes and developments in ICT use in primary schools across Australia. This paper focuses on the initial development of a three dimensional framework for describing the complexity of school environments in relation to ICT adoption.

The DEST report Making better connections (Downes, Fluck, Gibbons, Leonard, Matthews, Oliver, Vickers \& Williams, 2001) gathered together information regarding ICT use in schools to answer the question 'What educational outcomes do schools and systems hope to achieve by increasing the extent to which ICT are integrated into classroom practice?' and examined the implications for planning and implementing effective professional development for teachers. The report provides a classification of school ICT use that represents significant progress towards a comprehensive framework for the description ICT integration in schools. An overview of the Downes et al. (2001) classification follows:

Type A: ICT as an object of study

- Encouraging the acquisition of ICT skills as an end themselves;

- ICT skills are taught as a separate subject; and

- Traditional subjects continue to be taught the same.

Type B: ICT as tool for learning

- Using ICT to enhance students' abilities within the existing curriculum;

- Whole school focuses on integration of ICT; and

- Some teachers change their pedagogical approach through the use of ICT while others continue to use existing pedagogical approaches. 
Type C: ICT as integral to both subject matter and pedagogy

- ICT transforms the classroom;

- Introducing ICT as an integral component of broader curricular reforms; and

- Teacher's pedagogy and content are changed through the use of ICT.

Type D: ICT as integral to reform of schooling

- ICT transforms education;

- Organisation and structural changes take place to schooling itself;

- Student learning through authentic, challenging multidisciplinary tasks;

- New roles for teachers and students;

- Culture of inter-related learning within and beyond the school; and

- Changes in the professionalism of teachers.

The Downes et al. (2001) classification covers the aspects of motivation for ICT use, pedagogical approach, impact on curriculum content and school organisation. Each of these aspects also emerged in the e-Learning grants study reported in this paper, however, two additional aspects were found to be important; the level of technology infrastructure and teacher perceptions of innovation (relevant to teacher change). The interrelationships between all these aspects warrants further investigation, as does the assumption that professional development is the key to increasing the integration of ICT.

Background information from recent research for the four over-arching aspects of infrastructure, motivation, pedagogy and innovation is presented below, followed by an explanation of the three dimensional framework.

\section{Infrastructure}

Computers are now regarded by policy makers and teachers to be a part of the basic infrastructure of primary schools. The density of computers in schools in Australia has increased significantly over the past fifteen years. By 2002 the average ratio of computers to students in state and territory government schools was 1 to 5.3 (calculated using figures from MCEETYA, 2002). Achieving such ratios has been a direct result of the policies of state and territory governments, and, given that this significant increase in computer density in primary schools has been achieved in a relatively short period of time, it is understandable why such achievements are described as innovative. 
The picture that emerges, for government schools in particular, from the various policy documents in 2002, is that the basic ICT infrastructure of a primary school across all sectors and all states has:

- a ratio of computers to students between 1:4 and 1:8 (with some Catholic and small independent schools having ratios of 1:10);

- an increasing number of computers that are less than three years old;

- computers that use a standard suite of software (Standard Operating Environment or SOE):

- a local area network connecting computers in the school (ranging from some to all);

- access to the Internet (phone, cable, ISDN, satellite, optic fibre); and

- connectivity to a wide area network maintained and managed by an education system.

Therefore it can be assumed that the average teacher has at least a basic access standard to computer technology. However, efficient maintenance of a school's technology infrastructure is required, and this should not be underestimated as a factor in determining a teacher's use of ICT (Downes et al, 2001; Sugar et al, 2004).

\section{Motivation}

Motivation is the entire set of factors (i.e. motives) that compel an individual to respond and has a directive, sustaining quality that energises and maintains learning activities. Decisions made by teachers about the use of computers in their classrooms and schools are likely to be influenced by multiple factors including the accessibility of hardware and relevant software, the nature of the curriculum, personal capabilities, and constraints such as time. However, there is substantial evidence to suggest that teachers' beliefs in their capacity (both individually and collectively) to work effectively with technology (self efficacy) are a significant factor in determining patterns of classroom computer use and innovation (Albion, 1999; Bandura, 1997; Pintrich \& Schunk, 2002; Russel, Bebell, O’Dwyer \& O'Connor, 2003).

\section{Pedagogy}

Pedagogy embodies knowledge and skills, classroom management, and overall effective teaching practices and so is a complex blend of professional knowledge and practitioner skills (Lovat \& Australian Council of Deans of Education, 2003). The teacher's own pedagogical beliefs and values play an important part in shaping technology mediated learning opportunities (Grabe \& Grabe, 2004; Higgins \& Moseley, 2001). 
The research literature on ICT use and pedagogy generally distinguishes between teacher centred approaches and student centred approaches, and is sometimes associated with innovative classroom practice (Scrimshaw, 2004). Distinction is also often made between ICT use involving lower order learning tasks and higher level cognitive engagement. A growing body of research (for example, Barker, 1999; Goodyer, 1999; Hannifin, 1999; Hayes, Schuck, Segal, Dwyer \& McEwen, 2001) identifies the potential of computer based technologies to transform pedagogy in the following ways:

- A shift from instructivist to constructivist education philosophies;

- A move from teacher centred to student centred learning activities;

- A shift from a focus on local resources to global resources; and

- An increased complexity of tasks and use of multimodal information.

It is clear then, that the role of the teachers, in terms of the pedagogy they bring to learning experiences involving ICT, is a critical factor in determining the nature of ICT use. However, the context of a particular school must also be considered, as the organisational culture of the school appears to be a great influence on teaching style (Di Benedetto, 2005).

\section{Innovation}

Innovation in the first instance is the act of departing from the traditional, and frequently involves developing practices, policies or approaches, or, using new methods or objects such as using computers in management or teaching and learning. Both internal and external forces (Yee, 1998) drive the need for schools to change and to innovate in order to change. In educational settings, external forces may include the need to update practices in keeping with the findings of international research, and to continually conform to national trends and even community expectations. Internal forces may be the pressures created by curricular reform, the desire to improve student outcomes (either as a whole or particular groups of students) or in response to the collective or individual values of teachers.

The educational model of innovation frames innovation, in the broadest sense, as an idea, practice or object that is perceived as new by an individual or organisation (Rogers, 1995). Accordingly, the educational model of innovation focuses on the idea of the 'new': new learning objects, new ways of teaching, and new learning environments.

The idea of new learning objects, in the educational model, relates innovation to the adoption and diffusion of technologies within educational institutions (Dooley, 1999). In this respect, an innovative learning object may simply mean the utilisation of technologies not previously used, i.e., the technology itself as innovation (Robertson, 2000; 
Connell, 2000). In this case, an emphasis is placed upon the teaching and learning of ICT skills. Equally, a new learning object refers to the provision of traditional curriculum tasks via new technologies, that is, technology as a tool (Casey, 2000). Here, the emphasis is placed upon such themes as enhanced educational outcomes and student motivation.

Again, the role of the teacher is a critical factor, this time in terms of his or her perception of role of the technology and its 'newness' in relation to his or her own experience. Given the significance of the teacher's role in determining the use of ICT, it is obvious that research seeking to understand the level of integration of ICT in a school must focus on hearing the 'teacher's voice'.

\section{Method}

In the first year of the initiative, the e-Learning Grants program drew applications from 1300 primary schools in the government, Catholic and independent sectors. This represented about $16 \%$ of all primary schools in Australia. The schools were contacted individually during late 2003 to obtain their consent to use the information contained in their applications for this study. Four hundred and sixty four schools provided written consent and the data from them provided the basis for the formulation of the framework that is the focus of this paper. Schools that consented represented $36 \%$ of the total number of schools which applied and almost $6 \%(5.8 \%)$ of the primary schools in Australia in 2002 (The National Report on Schooling in Australia, 2001). The sample from each state or territory was proportional to its total number of schools, except that Victoria was slightly over-represented and NSW slightly under-represented (Table 1).

Table 1: Percentage of schools in study compared with actual percentage of Australian schools

\begin{tabular}{|c|c|c|c|c|}
\hline $\begin{array}{c}\text { State or } \\
\text { territory }\end{array}$ & $\begin{array}{c}\text { Number } \\
\text { schools }\end{array}$ & $\begin{array}{c}\text { Percentage } \\
\text { of sample }\end{array}$ & $\begin{array}{c}\text { Actual \% of } \\
\text { schools }\end{array}$ & $\begin{array}{c}\% \\
\text { difference }\end{array}$ \\
\hline NSW & 118 & 25.3 & 33.0 & -7.7 \\
\hline VIC & 155 & 33.5 & 25.0 & +8.5 \\
\hline ACT & 22 & 4.8 & 1.0 & +3.8 \\
\hline NT & 7 & 1.5 & 2.0 & -0.5 \\
\hline TAS & 10 & 2.2 & 3.0 & -0.8 \\
\hline WA & 36 & 7.6 & 10.0 & -2.4 \\
\hline SA & 41 & 8.9 & 8.0 & +0.9 \\
\hline QLD & 75 & 16.2 & 18.0 & -1.8 \\
\hline
\end{tabular}

While the sample of schools might be considered as representative in terms of sample size, schools applying for a grant may be displaying a motivation toward ICT adoption not necessarily present in non-applicant schools. 
In their applications for the e-Learning Grants, schools were asked to provide:

- some basic statistical information about the school (education sector, state, student population, etc),

- a description of their project outlining why they felt that it was innovative,

- information about their current use of ICT,

- the motivation for their project,

- expected outcomes with a particular emphasis on literacy and/or numeracy,

- a proposed budget, and

- an overview of the people involved.

The researchers adopted the theoretical perspective of a constructivist use of grounded theory (Strauss \& Corbin, 1998; Denzin \& Lincoln, 2003) to discover the multiple 'realities' of teacher perceptions and understandings embedded in the text of the applications. The 'content analysis' processes of coding, identification of concepts, creation of categories and interpretation of relationships allowed the construction of a theoretical framework for understanding the essence of the information provided by the teachers.

Initially, 70 applications were reviewed as a pilot study and from this a database shell was developed. The larger descriptive fields of data were further examined independently by the researchers using content analysis processes to determine the incidence of phenomena (categories of description), particularly those that might reveal the relationship between teacher perceptions of ICT infrastructure, pedagogy and classroom practice, motivation and innovation.

Three consistent themes or 'dimensions' emerged from a comparison of the researchers' analyses, which essentially described the 'what', 'why' and 'how' of ICT use by schools in the context of their proposed innovative projects. Within each dimension, several subcategories (or types) were identified and a set of descriptors was compiled and validated through a process in which each researcher applied the descriptors to the same set of applications and then compared their interpretations. These dimensions and subcategories were tested against current policy and research literature and refined accordingly. For example, the common themes that emerged in the teachers' explanations of innovation were checked for alignment with the themes found in the research and theoretical literature on innovation and education. The resulting framework was then applied to the detailed analysis of each of the 464 applications. The following section provides a description of the resulting three-dimensional framework, together with 
some national level data that provides an example of how the framework can be used to present a comprehensive picture of the adoption of ICT in Australian schools, in this case, a 2002 picture.

\section{A three dimensional framework}

The identified dimensions of 'ICT Infrastructure' (the 'what'), 'Motivation and ICT use' (the 'why') and 'Innovation and pedagogy' (the how'), and their sub-categories, are presented in Table 2. The vertical alignment of the subcategories is deliberate, as strong relationships between the types within each dimension were found, suggesting the types may be hierarchical (so could possibly be considered as 'levels').

Table 2: Three dimensional analysis framework

\begin{tabular}{|c|c|c|c|c|}
\hline Dimension & Subcategory 1 & Subcategory 2 & Subcategory 3 & Subcategory 4 \\
\hline $\begin{array}{c}\text { ICT } \\
\text { infrastructure }\end{array}$ & $\begin{array}{c}\text { Disconnected } \\
\text { environment }\end{array}$ & $\begin{array}{c}\text { Initially } \\
\text { connected } \\
\text { environment }\end{array}$ & $\begin{array}{c}\text { Established } \\
\text { connected } \\
\text { environment }\end{array}$ & $\begin{array}{c}\text { Multifaceted } \\
\text { connected } \\
\text { environment }\end{array}$ \\
\hline $\begin{array}{c}\text { Motivation and } \\
\text { ICT use }\end{array}$ & $\begin{array}{c}\text { Situational - } \\
\text { reactive }\end{array}$ & Skills oriented & Proactive - higher order \\
\hline $\begin{array}{c}\text { Pedagogy and } \\
\text { innovation }\end{array}$ & $\begin{array}{c}\text { ICT as an } \\
\text { innovative } \\
\text { object }\end{array}$ & $\begin{array}{c}\text { ICT as a } \\
\text { curriculum } \\
\text { Tool }\end{array}$ & \multicolumn{2}{|c|}{ New learning environment } \\
\hline
\end{tabular}

\section{Dimension 1: Infrastructure levels in primary schools}

Schools were asked to describe in the applications their existing technology resources and how they were used. The four infrastructure levels identified from this information, using the process outlined above, are described in terms of the key characteristics.

\section{Level 1: The disconnected environment}

The school's ICT infrastructure is limited and comprises only a small number of computers, most not connected to any type of network. In this environment there is an emphasis on increasing access to the technology, generally by providing more computers, to reduce the ratio of computers to students, and constructing a network. Descriptions of this level of ICT infrastructure, of the disconnected environment, are characterised by:

- Small numbers of computers, usually one or two per classroom (i.e. ratios of between 1:25 and 1:30);

- Limited access to the Internet, usually through the library; and

- Computers in the school are generally not networked and operate as 'stand alone' workstations. 


\section{Level 2: The initially connected environment}

The ICT infrastructure is slightly more developed and utilised, but descriptions of this environment recognise greater potential for the use of networked computers within the school environment, and often focus on increasing the quantity and connectivity of computers. The descriptions are characterised by:

- Increased numbers of computers in the school (typically between 1:10 and 1:15);

- Small numbers of networked computers;

- Internet access is available but only to a small number of computers in areas such as the library or specific classrooms; and

- Internet access is usually slow with restricted bandwidth.

\section{Level 3: The established connected environment}

The ICT infrastructure is well established and a school's local area network is in operation. These schools often describe the desire to add additional resources to the infrastructure to expand its use. Descriptions are characterised by:

- Increased numbers of computers in the school. The density of computers is consistent with government statistics;

- Computers are generally less than three years old;

- Almost all computers are connected to the school's local area network;

- Broadband access to the Internet is available and reticulated throughout the school;

- Emphasis on access to the Internet, particularly as an information resource;

- All networked computers have Internet access. Internet access on all computers is considered a priority;

- Increased use of peripheral devices such as scanners, digital cameras and networked printers;

- Multimedia resources (digital video and data projectors) are beginning to be used in teaching and learning;

- High density computer areas such as 'computer labs', 'technology centres', 'technology resource centres' are created; and

- A concentration of expertise and competence in a small number of teachers usually manifested in the form of a 'computer teacher'.

\section{Level 4: Multifaceted connected environment}

In schools in this level ICT has matured to become an integral part of the school environment, with well established infrastructure and commun- 
ication mechanisms (websites and email use) reaching beyond the school. The opportunities for teaching and learning provided by the infrastructure are beginning to change the operation of the school and how teachers conceptualise teaching and learning. Descriptions are characterised by:

- Broadband access to the Internet available on all computers;

- All computers connected to a high speed LAN;

- Increased provision of network management systems, both internally and externally, resulting in increased reliability and stability;

- Increased use of multimedia devices such as digital video, digital cameras;

- Increased use of the LAN for teaching and learning as well as administration and communication. The LAN is a critical component of teaching and learning programs;

- Email used regularly by staff and students;

- Exploration and experimentation with the options provided by the Internet and school LAN and broadband Internet access;

- Emphasis on the Internet as an information resource is shifting to incorporate communications potential;

- The school website is a critical part of the school;

- ICTs are bringing about a change in the way the technological infrastructure and the teaching and learning environments of the school are conceptualised; and

- Experimentation with school organisation, classroom design and furniture, etc.

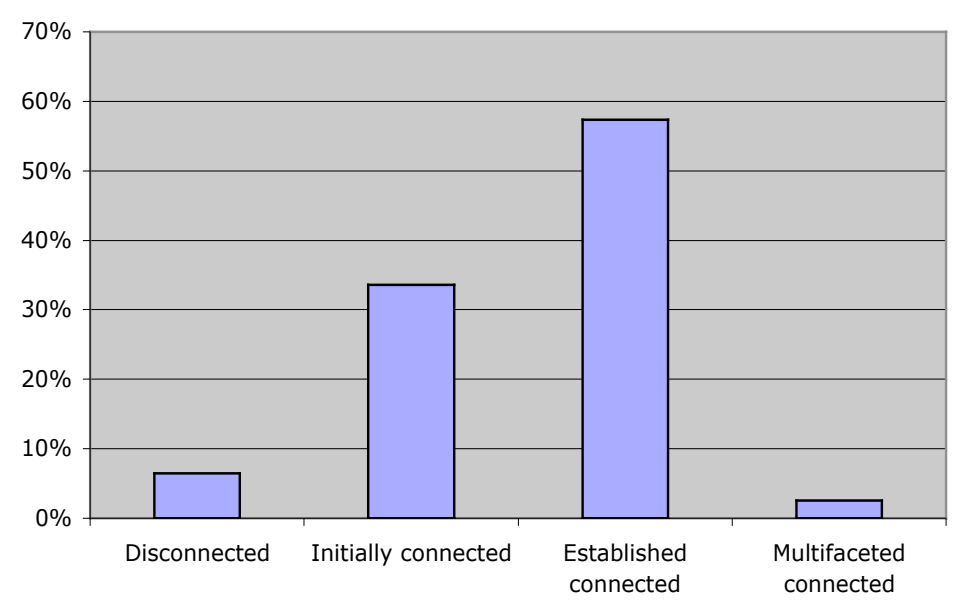

Figure 1: The 2002 national picture: Levels of infrastructure $(n=464)$ 


\section{The national picture of infrastructure}

As shown in Figure 1, the vast majority of schools (91\%) described computer environments that were either 'initially connected' environments $(34 \%)$ or established connected environments $(57 \%)$. Very few schools described infrastructures that could be categorised as Level 1 - Disconnected $(6.5 \%)$ or as Level 4 - Multifaceted connected $(2.6 \%)$.

\section{Dimension 2: Teacher motivation and ICT use}

The motivation descriptions, that is, the explanations of 'why' the ICT projects are being proposed, reflect how teachers respond to the relative significance of the influencing forces in a particular context. Three types of motivation and ICT use were identified.

\section{Type 1: Situational - reactive}

The project motivation is based on the specific school context and the reason for the project is defined in terms of meeting the learning needs of students or specific groups of students. In this sense, the initiative is a reaction to the internal forces operating within the particular school. The explanations of motivation usually involve identifying the areas of deficit (a reflection of the values of the teachers and school), particularly in terms of student needs.

The project descriptions contain goals such as:

- Providing opportunities for disadvantaged students (e.g. distance, socio-economic disadvantage, etc);

- Increasing access to technology (particularly in remote and rural areas);

- Addressing negative attitudes to literacy/numeracy or to learning in general; and

- Promoting 'life skills'.

The motivation statements of schools in this type frequently refer to the pressures, deficits or disadvantages for their students, school, teachers and community and how they, as teachers, react to these pressures. A number of themes were woven into the motivation descriptions. The three predominant themes of motivation were Teacher Centred, Student Centred, and Resource Centred.

\section{Type 2: Skills oriented}

In this category, the motivation for the project is focused on students and staff acquiring technological skills and competencies related to the specific technologies available within the school and how ICT can be used to support curriculum outcomes. Innovation in this type involves integrating 
the skills necessary to perform tasks embedded in curriculum areas; it is frequently described in terms of doing what is normally undertaken within the school but the innovation is that it will now be done using ICT.

The explanations of motivation and the project descriptions focus on developing and increasing skills, for example:

- Core IT skills;

- Abilities in ICT;

- Research and locating information skills;

- Multimedia construction;

- Expertise in ICT;

- Integration of technologies in the curriculum; and

- The quality of student publications.

There were three identifiable sub-groupings of motivation according to whether focus was on developing student ICT skills, teacher ICT skills, or teacher skills in integrating ICT in the curriculum.

\section{Type 3: Proactive - higher order}

This type of motivation is characterised by experimentation and exploration of new ways of teaching and learning, often for the promotion of new ways of thinking or higher order thinking skills. In this sense the projects are proactive because of the forward looking nature of the goals and the departure from previous methods. Innovation in this 'type' reflects the value that teachers place on a broader and more integrated curriculum, but it is also built on teacher and student competencies and an ICT infrastructure that can support such innovation.

The explanations of motivation and the project descriptions include features such as:

- Pedagogical frameworks;

- Personal construction of knowledge;

- Deep knowledge, synthesis, critical reflection;

- Open ended outcomes;

- Collaboration within and / or beyond the school;

- Digital multimedia creation;

- Net conferencing;

- Global publication and critique; and

- Cultural exchanges online.

\section{National picture of motivation and ICT use}

As can be seen in Figure 2, the majority $(72 \%)$ of the schools described their motivation for the proposed project and the reasons for using ICT in the 
project in terms of developing the technological skills of students and teachers as a means of enhancing curriculum outcomes (Type 2: Skills oriented).

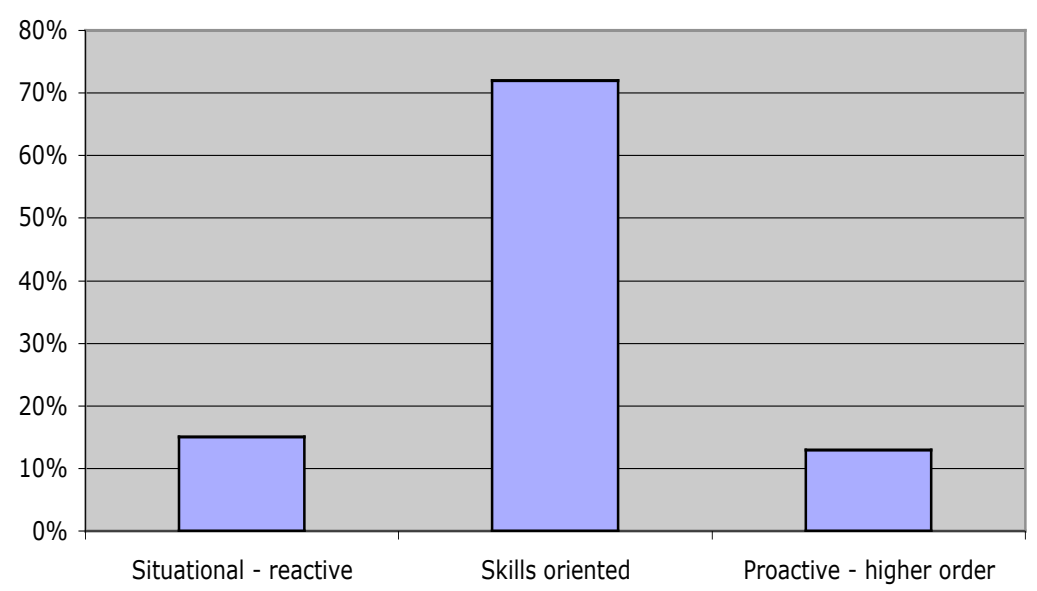

Figure 2: The national picture: Types of motivation and ICT use $(n=464)$

Of the remaining schools, $15 \%$ were reacting to a problem or need specific to their own school or to a group of students within the school (Type 1: Situational - reactive). Only $13 \%$ of the schools were motivated to explore new ways of thinking and learning afforded by the technologies (Type 3: Proactive - higher order).

\section{Dimension 3: Pedagogy and innovation}

Three subcategories or modes of pedagogy emerged from the descriptions of projects provided by teachers in the applications. The teacher descriptions not only revealed how they perceive the relationship between ICT, their views on student learning and their approaches to teaching, but also what they considered to be innovative about their projects (see Way \& Webb, 2007).

\section{Mode 1: ICT as innovative objects}

This mode is characterised by an emphasis on the 'newness' of the technology itself and the project's focus on 'learning about the technology' and bringing new technologies into the classroom. The rapid changes that appear to be inherent in hardware and software create a perception of constant 'newness'. New technological objects are more likely to be used if the classroom practice of the teacher is not challenged by the new object 
because the teacher's pedagogical approach can accommodate the 'new' technology, i.e. new technology but not new pedagogy.

The project descriptions in this type include references to factors such as:

- Computer labs;

- Basic skills in literacy and numeracy;

- Core IT skills (word processing);

- Increased confidence and ICT experience;

- Raising expectations;

- Efficiency of organisation, time, access to information, planning; and

- Motivation of reluctant learners.

\section{Mode 2: ICT as a curriculum tool}

This mode is characterised by references to how the technology can improve educational outcomes such as those defined in curriculum documents. The technology becomes a teaching and learning tool. The increased efficiency presented by the technologies is perceived as the innovation.

The project descriptions in this category emphasise factors such as:

- Learning opportunities provided through the use of ICT;

- Curriculum delivery enhancement;

- ICT as an educational tool, powerful tool, information tool, productivity tool, support tool, tool to enhance learning;

- Integrating ICT across learning areas;

- Online units of study;

- Designing rich learning resources;

- A tool for assessment; and

- The development of descriptors for competencies, achievement and curriculum outcomes.

\section{Mode 3: New learning environment}

In this subcategory, shifts in pedagogy are integral to the innovation of the project. The technologies bring into question current approaches to teaching and learning and school organisation. Innovation in this 'mode' allows or produces new or creative learning environments and new ways of teaching and learning.

The project descriptions feature factors such as:

- Meaningful and relevant learning strategies;

- Learning styles or multiple intelligences,

- Inquiry oriented online tools; 
- Collaboration and cooperation; and

- New ways of learning, personalised, realistic, self paced, self directed, non-linear, self assessed.

Learning environments are described as:

- Virtual;

- Real time synchronous;

- Geographically remote,

- Collaborative,

- Networked;

- Global;

- Communities; and

- E-learning spaces.

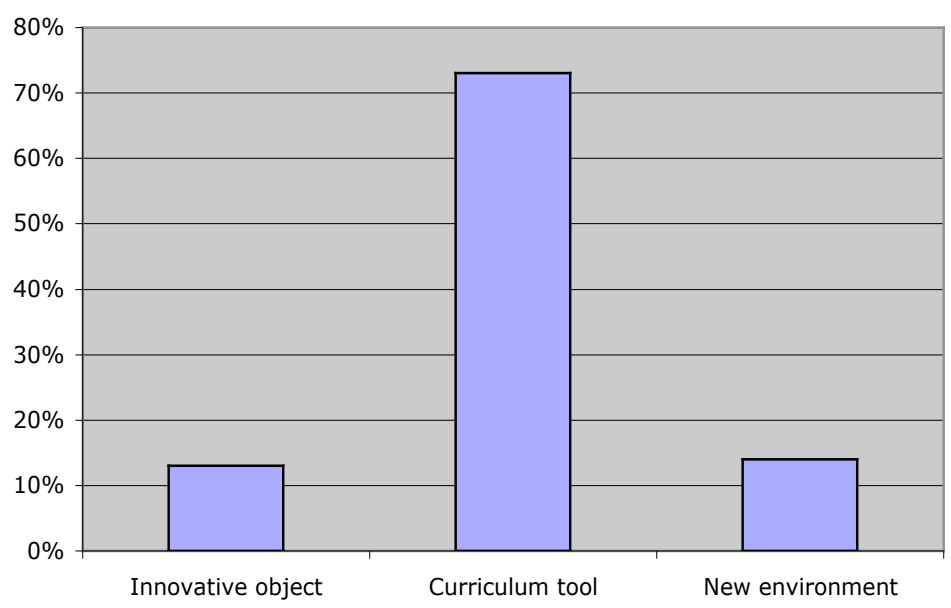

Figure 3: The national picture: Modes of pedagogy and innovation $(n=464)$

\section{National picture of pedagogy and innovation}

As shown in Figure 3, the predominance of schools categorised as Type 2: ICT as a curriculum tool (73\%) suggests that the majority are using ICT as a tool to enhance traditional approaches to teaching and learning, where innovation is described in relation to achievement of current curriculum outcomes. While the resources are new and exciting, the learning goals and pedagogy are essentially the same as without the technology.

Approximately $14 \%$ were using technology to explore new pedagogical approaches (Type 3) that in turn, create new learning environments while $13 \%$ of schools are exploring the 'new' technologies (Type 1). 


\section{Relationships between the three dimensions}

\section{Interaction between infrastructure and motivation}

Further examination of the data was carried out to determine whether there were interactions between the level of ICT infrastructure and the motivation type. The resulting information can be used to answer such questions as, 'Are schools with a low level of Infrastructure usually Type 1 Motivation and ICT use?'

Table 3: Interactions between infrastructure level and motivation type $(n=464)$

\begin{tabular}{|l|c|c|c|c|}
\hline \multirow{2}{*}{\multicolumn{1}{|c|}{ Motivation type }} & \multicolumn{4}{|c|}{ Infrastructure level } \\
\cline { 2 - 5 } & $\begin{array}{c}\text { Disconn- } \\
\text { ected }\end{array}$ & $\begin{array}{c}\text { Initially } \\
\text { connected }\end{array}$ & $\begin{array}{c}\text { Established } \\
\text { connected }\end{array}$ & $\begin{array}{c}\text { Multifaceted } \\
\text { connected }\end{array}$ \\
\hline Situation reactive & $23.38 \%$ & $36.36 \%$ & $40.26 \%$ & $0.00 \%$ \\
\hline Skills oriented & $4.37 \%$ & $37.01 \%$ & $57.47 \%$ & $1.15 \%$ \\
\hline Proactive - high order & $1.35 \%$ & $29.73 \%$ & $55.41 \%$ & $13.51 \%$ \\
\hline
\end{tabular}

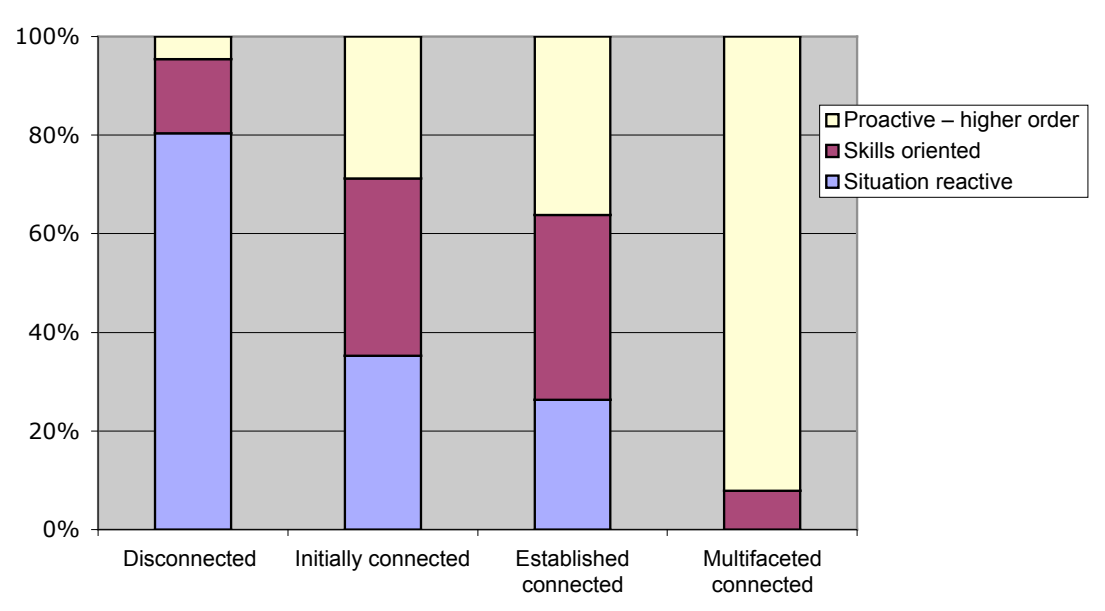

Figure 4: Interactions between infrastructure level and motivation type

Table 3 and Figure 4 present the percentages of schools that have the characteristics that match the intersection of a particular infrastructure level and a particular motivation type. A relationship appears to exist between motivation type and infrastructure level. Schools with Type 1 Motivation (Situational - reactive) tended to have lower levels of infrastructure. Schools with higher levels of infrastructure were more likely to have Type 3 Motivations (Proactive-higher order). Just over $70 \%$ of 
schools in the sample have infrastructure levels of 2 or 3 and Type 2 Motivation (Skills oriented).

Where the level of infrastructure in a school is perceived to be relatively low, the motivation for using ICT is described in terms of the deficits in the level of infrastructure or the level of perceived disadvantage within the school. Where the level of ICT infrastructure is perceived to be high and is beginning to change the environment of the school, schools are more likely to describe their motive for using the infrastructure in terms of the opportunities the technologies provide for more complex, integrated learning experiences that involve higher skills and thinking.

\section{Interaction between motivation and pedagogy}

Further examination of the data was carried out to determine whether there were interactions between the type of motivation and the mode of pedagogy/innovation. The resulting information can be used to answer such questions as, 'Are schools with 'higher' types of motivation likely to also have 'higher' modes of pedagogy?'

Table 4 and Figure 5 present the percentages of schools that have the characteristics that match the intersection of a particular motivation type and a particular pedagogy type. Over $60 \%$ of schools had a Type 2: Skills oriented motivation and a Mode 2: ICT as a curriculum tool approach to pedagogy. There was, however, also an interaction between subcategories 1 and 3 for both motivation and pedagogy.

Schools with a Type 3 Motivation (Proactive-higher order) were more likely to have Mode 3 Pedagogy (New learning environment). Conversely, Schools with Type 1 Motivation (Situational - reactive) were more likely to be in Mode 1 Pedagogy (ICT as an innovative object). While the numbers of schools in subcategories 1 and 3 for both pedagogy and motivation are relatively small, the data suggest that there is a link between the motivation for using technology in a school and the pedagogical approaches that will be adopted within the school.

Table 4: Interaction between motivation and pedagogy / innovation $(n=464)$

\begin{tabular}{|l|c|c|c|}
\hline \multicolumn{1}{|c|}{$\begin{array}{c}\text { Motivation } \\
\text { type }\end{array}$} & $\begin{array}{c}\text { Pedagogy Mode 1 - } \\
\text { Innovative object }\end{array}$ & $\begin{array}{c}\text { Pedagogy Mode 2 - } \\
\text { Curriculum tool }\end{array}$ & $\begin{array}{c}\text { Pedagogy Mode 3 - } \\
\text { New learning } \\
\text { environment }\end{array}$ \\
\hline $\begin{array}{l}\text { Type 1 - Situation } \\
\text { reactive }\end{array}$ & $23.38 \%$ & $36.36 \%$ & $40.26 \%$ \\
$\begin{array}{l}\text { Type 2 - Skills } \\
\text { oriented }\end{array}$ & $4.37 \%$ & $37.01 \%$ & $57.47 \%$ \\
\hline $\begin{array}{l}\text { Type 3 - Proactive - } \\
\text { higher order }\end{array}$ & $1.35 \%$ & $29.73 \%$ & $55.41 \%$ \\
\hline
\end{tabular}




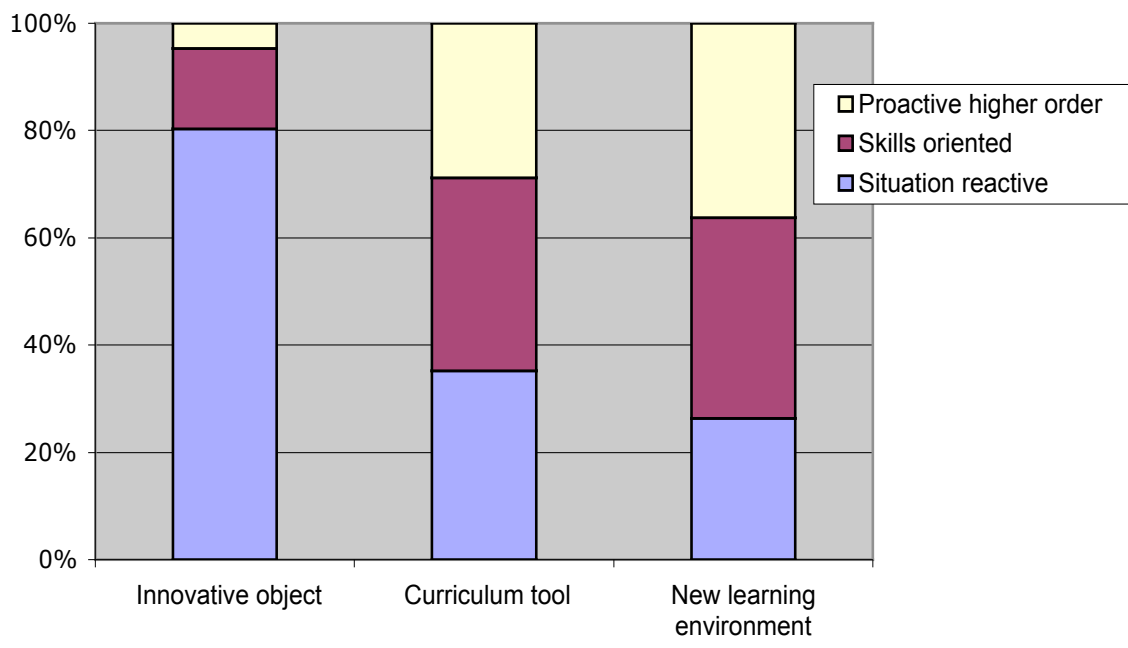

Figure 5: Interaction between motivation type and pedagogy/innovation mode

\section{Interaction between pedagogy and infrastructure}

Further examination of the data was carried out to determine whether there were interactions between the mode of pedagogy/innovation and level of infrastructure. The resulting information can be used to answer such questions as, 'Is the level of infrastructure an indicator of the mode of pedagogy/innovation?'

Table 5 and Figure 6 present the percentages of schools that have the characteristics matching the intersection of a particular pedagogy mode and a particular infrastructure level.

Table 5: Interactions between infrastructure level and pedagogy mode $(n=464)$

\begin{tabular}{|l|c|c|c|c|}
\hline \multirow{2}{*}{ Pedagogy mode } & \multicolumn{4}{|c|}{ Infrastructure level } \\
\cline { 2 - 5 } & $\begin{array}{c}\text { Disconn- } \\
\text { ected }\end{array}$ & $\begin{array}{c}\text { Initially } \\
\text { connected }\end{array}$ & $\begin{array}{c}\text { Established } \\
\text { connected }\end{array}$ & $\begin{array}{c}\text { Multifaceted } \\
\text { connected }\end{array}$ \\
\hline Innovative object & $2.9 \%$ & $4.6 \%$ & $4.1 \%$ & $0.0 \%$ \\
\hline Curriculum tool & $3.1 \%$ & $29.0 \%$ & $43.1 \%$ & $1.0 \%$ \\
\hline New learning environment & $0.0 \%$ & $2.9 \%$ & $7.6 \%$ & $1.5 \%$ \\
\hline
\end{tabular}

Schools with a higher level of technological infrastructure are more likely to adopt pedagogies described as Mode 3 (New learning environment), that promote higher order thinking. The technological infrastructure of the school and how the school intends to use the technologies is perceived as 
having the capacity to change the totality of the school environment - to change teaching and learning.

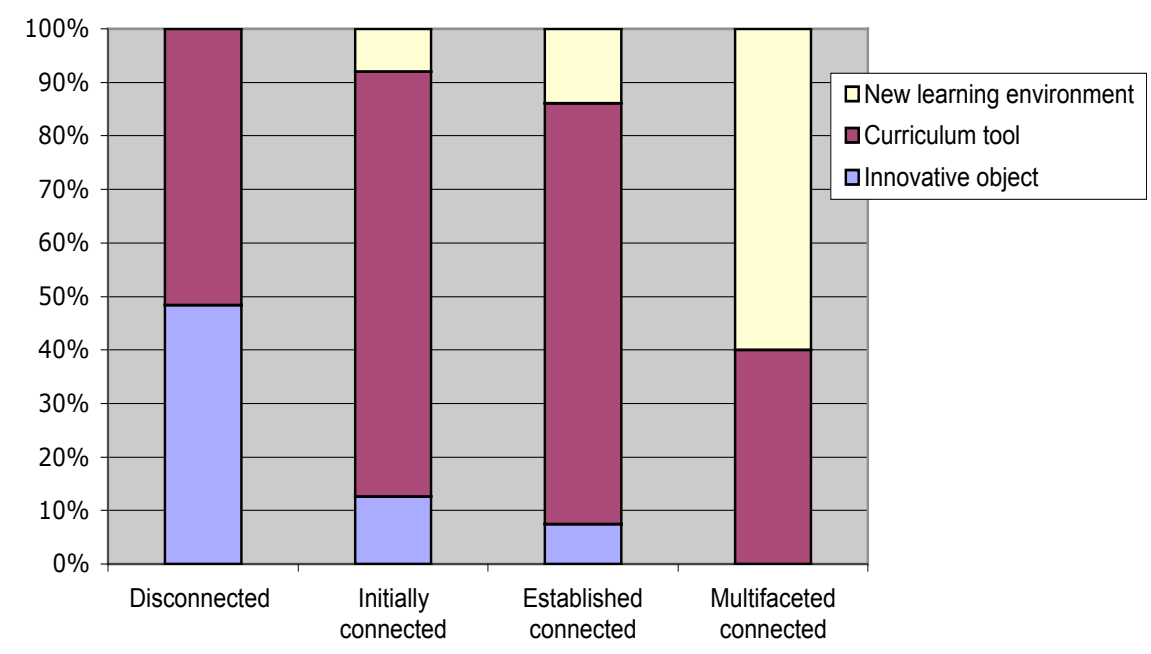

Figure 6: Interactions between infrastructure level and pedagogy mode

Schools with lower levels of infrastructure (Level 1) are more likely to adopt pedagogical approaches consistent with Mode 1 (ICT as innovative object) where the focus is on the technologies and integrating the technologies into the current practices of the school.

\section{Summary of inter-dimensional relationships}

Schools that are motivated to explore the potential higher order thinking and new learning tasks are more likely to engage in pedagogies that would result in the creation of new learning environments. Schools that are motivated to address specific deficits in their students, school or community are more likely to be reacting to the technologies as new and innovative objects. The data suggest there is a link between the motivation for using technology in a school and the pedagogical approaches that will be adopted within the school.

There is also a strong link between the infrastructure and pedagogy. Almost a third of the schools specifically indicated that they had a 'lab', 'learning technology resource room', 'computer classroom' or some other 'technology resource centre'. The pedagogies described in association with specialist teachers and computer lab facilities are generally consistent with 
a transmission approach, as opposed to the distribution of resources throughout classrooms where constructivist pedagogies are more likely to prevail. Teachers who use constructivist approaches are more likely to use smaller groups and differentiate tasks and resources for different groups. Hence, there is a potential conflict between the current pedagogical trends towards constructivist based learning and the location of the majority of the school's computers in one specialist room.

Schools with a higher level of technological infrastructure are more likely to adopt pedagogies regarded as transformative and that lead to the creation of new learning environments. Schools with lower levels of infrastructure are more likely to adopt pedagogical approaches where the focus is on the technologies and integrating the technologies into the current practices of the school.

This study has found that, irrespective of the level of technological infrastructure that exists in an individual school, teachers believe that they have the potential to develop innovative projects. The innovation may be in the use of a new technology, using a technology in a new way within the curriculum or using the technologies to assist in the creation of new learning environments.

\section{The typical Australian primary school}

The majority of the schools (77\%) in 2002 had project descriptions characterised by:

- ICT Infrastructure Level 2 - Initially connected environment or Level 3 Established connected environment;

- Motivation and ICT use Type 2 - Skills oriented; and

- Pedagogy and innovation Mode 2 - ICT as a curriculum tool.

These schools typically have a computer to student ratio approaching the national average and have most of their computers connected to the school network. Many computers are distributed throughout the school, and classroom computers are commonly used in association with the computers located in computer labs and/or the library. The computers also have access to the Internet. Both students and teachers are focussed on developing the skills necessary to use the technology as tools for learning, teaching and communication. The opportunities presented by the technologies are perceived in terms of how the technologies can be used to enhance the curriculum priorities of the school. The technologies are described as 'educational tools', particularly effective when used in association with information processing and students using multimedia technologies to enhance literacy outcomes. 


\section{Conclusion: Meeting the challenge of integrating ICT}

Australian schools are faced with the challenge of interpreting system level ICT policies to best serve their own school's agenda. Factors such as the school's world view regarding learning and knowledge, motivations for incorporating ICT and social-cultural aspects, such as specific needs of the students, parents and the community, will influence the nature of ICT use.

Teachers' articulations of their motivation, their pedagogies and the technological infrastructure of schools across Australia provided a 'what', 'why' and 'how' framework to understand the ways in which innovation in the use of ICT occurs within the context of an individual school. Application of the three-dimensional framework of Infrastructure, Motivation and Pedagogy/innovation, developed specifically to analyse school ICT projects, revealed some of the crucial factors that determine the nature of a school's approach to integrating ICT and developing innovative practice. If the framework is indeed hierarchical, as the evidence suggests, then the majority of Australia's primary schools have reached a mid-point in the development of ICT integration, and perhaps, given time and continued support, will move into the next phase. However, the question of whether this development can be accelerated remains unanswered. Indeed, Cartwright \& Hammond (2007) emphasise "the notion that all schools are somewhere along a path of ICT adoption that will ultimately lead to a transformation in teaching and learning is unrealistic" and that the shift to effective integration of technology by teachers is "a complex and long term enterprise" requiring strong intervention (p.405). However, Baskin \& Williams (2006) in their study of 18 schools, reported a broad acceptance "that ICTs will at some stage of evolution provide accessible, flexible learning experiences, increased administrative efficiency, integration of functions, and improved processes across the school, despite the fact that few schools in this study have tangible experience of these advantages" and express concern over the large gap between levels of ICT integration in schools (Baskin \& Williams, 2006:466).

\section{Future application of the framework}

The framework is currently being applied as a research tool for analysing elearning grant applications for the year 2005. It is a painstakingly slow process, with over 1000 applications to be individually and 'manually' analysed. The apparent hierarchical nature of the 'types' within each of the three dimensions provides a means of detecting and describing changes in the nature of ICT use in the schools across Australia, and so reveal trends. The new data will also provide the researchers with the opportunity to test the 'robustness' of the framework and its capacity to describe the evolution of ICT practices in schools. Early results on the 35\% of the 2005 applications 
that focussed on integrated literacy and numeracy projects show a strong shift towards Mode 3 Pedagogy: New learning environment, incorporating problem solving, critical thinking, evaluation, creativity and communication beyond the classroom.

There is great potential for applying the framework to data collected directly from an individual school with the express purpose of 'locating' the school within the matrix. The three dimensions, and the interactions between the dimensions, provide a structure for understanding the complex factors within an individual school that determine the nature of ICT use and the identifying potential movement in infrastructure, pedagogy and motivation. This would enable teachers and policy makers to understand the potential for innovation within the context of an individual school and so strategically plan for needs such as professional development, expenditure on infrastructure and changes in school organisation.

Professional development may well be a critical factor to enhance the integration of ICT but only if it is matched with the school's particular needs (Sugar et al, 2004), specifically current levels of motivation, ICT use, infrastructure, pedagogy and innovation, and so supports teachers in accelerating a transition that has already begun across the school.

\section{Acknowledgement}

This study was funded by a grant from the Commonwealth Bank Foundation and the researchers appreciate their support. The full report Innovation and e-Learning in Australian Primary Schools 2002 (released 2005) is temporarily not available on the Internet but a copy can be obtained by contacting one of the authors. Readers should note that in 2007 the Commonwealth Bank Foundation shifted its school funding focus away from e-learning and these grants are no longer available.

\section{References}

Ainley, J., Banks, D. \& Flemming, M. (2002). The influence of IT: Perspectives from five Australian schools. Journal of Computer Assisted Learning, 18, 395-404.

Albion. P. (1999). Self-efficacy beliefs as an indicator of teachers' preparedness for teaching with technology. Association for the Advancement of Computing in Education.

Bandura, A. (1997). Self-efficacy: The exercise of control. New York: Freeman.

Barker, P. (1999). Using intranets to support teaching and learning, Innovations in Education and Training International, 36(1), 3-10.

Baskin, C. \& Williams, M. (2006). ICT integration in schools: Where are we now and what comes next? Australasian Journal of Educational Technology, 22(4), 455-473. http: / / www.ascilite.org.au/ajet/ ajet22 / baskin.html 
Bebell, D., Russell, M. \& O'Dwyer, L. (2004). Measuring teachers' technology uses: Why multiple-measures are more revealing. Journal of Research on Technology in Education, 37(1), 45-63.

BECTA (2004). A review of the research literature on barriers to the uptake of ICT by teachers. British Educational Communications and Technology Agency http:/ / partners.becta.org.uk/page_documents / research/barriers.pdf

Cartwright, V. \& Hammond, M. (2007). 'Fitting it in': A study exploring ICT use in a UK primary school. Australasian Journal of Educational Technology, 23(3), 390-407. http:/ / www.ascilite.org.au/ajet/ajet23/cartwright.html

Casey, G. (2000). What does computers across the curriculum really mean? Paper presented at ACEC Conference, Melbourne.

Connell, J. (2000). Integration of information technology into the curriculum innovation, equity and accountability. ACEC Conference, Melbourne.

Cuban, L. (2001). Oversold and underused: Computers in the classroom. Cambridge: Harvard University Press.

Denzin, N. K. \& Lincoln, Y. S. (2003). Strategies of qualitative inquiry (2nd ed.). Thousand Oaks, CA: Sage.

Di Benedetto, A. (2005). Does technology influence teaching practices in the classroom? Paper presented at the National Educational Computing Conference. Philadelphia, PA. http:// www.iste.org/Content/NavigationMenu/Re search /NECC_Research_Paper_Archives/NECC_2005/DiBenedetto-April-NECC05.pdf

Dooley, K. (1999). Towards a holistic model for the diffusion of educational technologies: An integrative review of educational innovation studies. Educational Technology \& Society, 2(4). http://www.ifets.info/journals/2_4/kim_dooley.html

Downes, T., Fluck, A., Gibbons, P., Leonard, R., Matthews, C., Oliver, R., Vickers, M. \& Williams, M. (2001). Making better connections: Models of teacher professional development for the integration of information and communication technology into classroom practice. Department of Education, Science and Technology. http: / / www.dest.gov.au/sectors / school_education/publications_resources / pr ofiles/making_better_connections.htm

Goodyer, A. (1999). Workshop on information and communication technologies and the curriculum. Office of the Board of Studies NSW. [viewed 14 May 2005] http:/ / w ww.boardofstudies.nsw.edu.au/archives/occasional_papers/occasionalp2_ict.html

Grabe, M. \& Grabe, C. (2004). Integrating technology for meaningful learning (4th ed.). Boston: Houghton Mifflin Company.

Hannafin, R. D. (1999). Can teacher attitudes about learning be changed? Journal of Computers in Teacher Education, 15(2), 7-13.

Hayes, D., Schuck, S., Segal, G., Dwyer, J. \& McEwen, C. (2001). Net Gain? The integration of computer-based learning in six NSW government schools 2000. The University of Technology, Sydney Faculty of Education Change and Education Research Group.

Higgins, S., \& Moseley, D. (2001). Teachers' thinking about information and communications technology and learning: Beliefs and outcomes. Teacher Development, 5(2), 191-210. 
Jamieson-Proctor, R. M., Burnett, P. C., Finger, G. \& Watson, G. (2006). ICT integration and teachers' confidence in using ICT for teaching and learning in Queensland state schools. Australasian Journal of Educational Technology, 22(4), 511-530. http: / / www.ascilite.org.au / ajet/ ajet22 / jamieson-proctor.html

Lovat., T. J. (2003). The role of the 'teacher' coming of age? Australian Council Deans of Education, Discussion Paper. http:/ / www.acde.edu.au/assets/pdf/role $\% 20$ of $\% 20$ eds $\% 20-\% 2024 \% 20$ june.pdf

MCEETYA (2002). National report on schooling in Australia 2001. Ministerial Council on Education, Employment, Training \& Youth Affairs. [viewed 22 Aug 2005]. http: / / cms.curriculum.edu.au/anr2001/

Phelps, R., Graham, A. \& Kerr, B. (2004). Teachers and ICT: Exploring a metacognitive approach to professional development. Australasian Journal of Educational Technology, 20(1), 49-68. http:/ / www.ascilite.org.au/ajet/ ajet20/phelps.html

Pintrich, P. R. \& Schunk, D. H. (2002). Motivation in education: Theory, Research, and applications (2nd ed.). Upper Saddle River, NJ: Merrill.

Robertson, E. (2000). Integrating learning technologies and collaborative Internet projects into the curriculum. Paper presented at ACEC Conference, Melbourne.

Rogers, E. (1995). Diffusion of innovations. Fourth edition. New York: The Free Press.

Russell, M., Bebell, D., O'Dwyer, L. \& O'Connor, K. (2003). Teachers' beliefs about and use of technology: Enchancing the use of technology for new and veteran teachers. Boston, MA: Boston College, Technology and Assessment Study Collaborative. [not found 20 Oct 2007\} http:/ / www.intasc.org/PDF/ useit_r5.pdf

Scrimshaw, P. (2004). Enabling teachers to make successful use of ICT. British Educational Communications and Technology Agency (Becta). [viewed 20 Sep 2006] http:/ / partners.becta.org.uk/page_documents/research/enablers.pdf

Smeets, E. (2004). Does ICT contribute to powerful learning environments in primary education? Computers $\mathcal{E}$ Education, 44, 343-355.

Strauss, A., \& Corbin, J. (1998). Basics of Qualitative Research (2nd ed.). California: Sage Publications, Inc.

Sugar, W., Crawley, F., \& Fine, B. (2004). Examining teachers' decisions to adopt new technology. Educational Technology and Society, 7(4), 201-213. http: / / www.ifets.info/others / download_pdf.php?j_id=25\&a_id=509

Way, J. \& Webb, C. (2007). Pedagogy, innovation and e-Learning in primary schools. Annual Conference of the Australian Association of Research in Education. Adelaide, Nov. http: / / www.aare.edu.au/06pap/way06728.pdf

Yee, J. A. (1998). Forces motivating institutional reform. ERIC Digest ED 421179. http: / / www.eric.ed.gov:80/ERICWebPortal/ contentdelivery/servlet/ERICSer vlet?accno=ED421179

Dr Jennifer Way, Faculty of Education \& Social Work, Building A35,

University of Sydney, Sydney NSW 2006, Australia.

Email: j.way@edfac.usyd.edu.au

Colin Webb, School of Education, University of Western Sydney, Locked

Bag 1797, Penrith South DC, NSW 1797, Australia. c.webb@uws.edu.au 